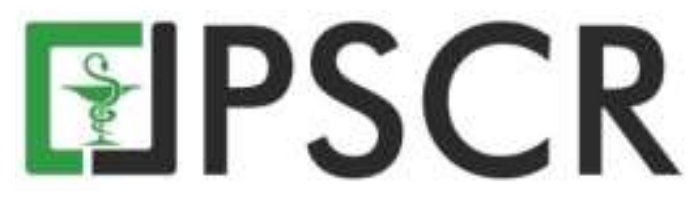

\title{
Potensi Ekstrak Daun Kangkung Darat (Ipomea reptans Poir) Sebagai Agen Sedatif Herbal
}

\author{
Wisnu Kundarto $^{1^{*}}$ dan Anafia Azzahra Pratiwi ${ }^{1}$ \\ Program Studi D3 Farmasi, Fakultas Matematika dan Ilmu Pengetahuan Alam, Universitas Sebelas Maret \\ *email korespondensi: wisnukundarto.apt@gmail.com
}

\begin{abstract}
Abstrak: Padatnya aktivitas dapat menyebabkan kualitas tidur menurun dan memicu gangguan tidur. Tanaman kangkung darat terbukti mempunyai efek sedasi pada dosis 2, 4, dan 8 mg/g BB dengan metode rotarod. Penelitian ini bertujuan melihat ada tidaknya efek sedasi dengan parameter refleks balik badan mencit pada variasi dosis yang lebih kecil. Penelitian ini termasuk penelitian eksperimental dengan rancangan post test only control group design. Penelitian ini menggunakan 30 ekor mencit Balb/c jantan dan terdiri dari 5 kelompok yaitu kontrol positif fenobarbital $6 \mathrm{mg} / \mathrm{kg} \mathrm{BB}$, kontrol negatif akuades, perlakuan dosis 8, 16, dan $32 \mathrm{mg} / \mathrm{kg} \mathrm{BB}$. Pengamatan dilakukan dengan mencatat durasi waktu tidur mencit dan dibandingkan antar kelompok. Hasil penelitian menunjukkan semua dosis memperlihatkan efek sedasi dan durasi waktu tidur meningkat sebanding dengan kenaikan dosis tetapi tidak berbeda signifikan pada dosis 16 dan $32 \mathrm{mg} / \mathrm{kg} \mathrm{BB}$.
\end{abstract}

Kata kunci: Efek sedative; Ipomea reptans Poir; durasi waktu tidur; refleks balik

\begin{abstract}
The Potency of Ipomea reptans Poir Leaves Extract as Natural Sedative Agent. Sleep quality may decrease due to higher activity and can induce sleep disturbance. Previously, Ipomea reptans Poir have sedative effect on dosage 2,4 , and $8 \mathrm{mg} / \mathrm{g}$ body weight with rotarod method. This research had aims to identify the sedative effect of Ipomea reptans on lower dosage using righting reflex method. This study was an experimental reseach with post test only control group design and using $30 \mathrm{Balb} / \mathrm{c}$ male mice. The animals were grouped into positive control (phenobarbital $6 \mathrm{mg} / \mathrm{kg}$ body weight), negative control (aquadest), dosage 8, 16, and 32 $\mathrm{mg} / \mathrm{kg}$ body weight. The duration of mice sleeping time then observed and compared between groups. The result showed all dosage exhibited sedation effect. Higher dosage gave longer mice sleeping time duration but not significantly different on dosage 16 and $32 \mathrm{mg} / \mathrm{kg}$ body weight.
\end{abstract}

Keywords: sedative effect; Ipomea reptans Poir; sleeping time duration; righting reflex 


\section{Pendahuluan}

Seperti halnya olahraga, tidur juga sangat penting untuk menjaga kesehatan tubuh. Tidur yang berkualitas dapat mengurangi stres dan membuat manusia memiliki energi untuk menjalani kehidupan yang aktif, produktif, dan memuaskan (Listiani, 2007). Padatnya aktivitas cenderung dapat memicu terjadinya gangguan tidur akibat kurang tidur (Ariani, 2010). Susah tidur lebih ditentukan pada kualitas tidur, bukan dari lama waktu tidur (Wijayakusuma, 2008). Jika dibiarkan, susah tidur dapat menurunkan produktivitas tubuh (Listiani, 2007).

Kangkung darat (Ipomea reptans Poir) banyak dimanfaatkan orang Indonesia sebagai sayuran dalam bentuk tumis kangkung. Jika dikonsumsi dalam jumlah banyak, beberapa orang mengaku merasakan kantuk. Anggara (2009) melaporkan pada dosis 2 mg/g BB, ekstrak kangkung darat terbukti dapat menimbulkan efek sedasi pada mencit dengan metode rotarod. Penelitian ini bertujuan untuk melihat ada tidaknya efek sedasi ekstrak kangkung darat pada variasi dosis yang lebih kecil dengan metode refleks balik badan.

\section{Metode Penelitian}

\subsection{Koleksi dan determinasi tanaman kangkung darat}

Tanaman kangkung darat diperoleh dari desa Ngruki Cemani Grogol Sukoharjo Jawa Tengah. Tanaman kemudian dideterminasi di Lembaga Penelitian dan Pengabdian Masyarakat Universitas Setia Budi Surakarta.

\subsection{Penyiapan simplisia dan pembuatan ekstrak kangkung darat}

Sebanyak 5 kg kangkung darat segar dicuci hingga tidak ada kotoran, lalu dipotong kecilkecil dan selanjutnya dikeringkan di bawah sinar matahari dengan ditutup kain hitam. Setelah kering, tanaman selanjutnya dihaluskan menjadi serbuk. Serbuk lalu dimasukkan ke dalam bejana dan ditambahkan penyari alkohol $70 \%$ dan diaduk setiap hari. Proses maserasi ini dilakukan dalam bejana tertutup selama 5 hari. Setelah selesai, maserat lalu dienapkan sehari semalam dan disaring. Filtrat hasil penyaringan lalu diuapkan di atas penangas air hingga diperoleh ekstrak kental.

\subsection{Pembagian kelompok}

Sebanyak 30 ekor mencit Balb/c jantan dibagi secara acak menjadi 5 kelompok. Mencit yang digunakan berusia 8 minggu, bobot 20-30 g, dan sehat secara fisik tanpa ada kelainan anatomi. Kelompok kontrol positif menggunakan fenobarbital dosis $6 \mathrm{mg} / \mathrm{kg}$ BB (Anggara, 2009). Kelompok kontrol negatif menggunakan akuades. Kelompok dosis menggunakan variasi dosis 8,16 , dan $32 \mathrm{mg} / \mathrm{kg}$ BB. Semua kelompok menggunakan rute pemberian secara per oral.

\subsection{Uji efek sedasi dengan metode refleks balik badan}


Pengujian ini dilakukan di Laboratorium Farmakologi Fakultas Kedokteran Universitas Sebelas Maret Surakarta. Sebelum dilakukan percobaan, terlebih dahulu mencit diadaptasikan dalam kandang standar dan diberi makan minum standar selama 1 minggu. Setelah masa adaptasi selesai, mencit dipuasakan dengan tetap diberi minum. Mencit selanjutnya diberikan perlakuan sesuai kelompok. Pengamatan dilakukan pada bejana pengamatan yang telah diberi alas kapas dan diterangi dengan lampu (Vogel, 2002). Setelah mencit terlihat tidur selanjutnya mencit segera ditelentangkan. Durasi waktu tidur diukur sejak mencit ditelentangkan sampai mencit dapat membalikkan badan. Durasi dicatat dalam satuan menit dan dibandingkan antar kelompok. Rerata durasi tiap kelompok dinyatakan dalam mean \pm SD.

\subsection{Analisis Data}

Data durasi yang didapat dianalisis dengan One Way ANOVA dan dilanjutkan uji Post Hoc Tests dengan $\mathrm{p}<0,05$ untuk mengetahui ada tidaknya perbedaan antar kelompok.

\section{Hasil dan Pembahasan}

\subsection{Hasil determinasi tanaman}

Determinasi tanaman bertujuan untuk menjamin kebenaran bahan yang digunakan. Determinasi dilakukan dengan panduan buku Flora (Steenis dan Eyma, 1978). Hasil determinasi menyatakan bahwa tanaman yang digunakan adalah Ipomea reptans Poir. Hasil determinasi tanaman adalah 1b-2b-3b-4b-6b-7b-10b-11b-12b-13b-14a-15a.golongan8.109a-110b-111b-112a113b-114b-115b.familia107. Convolvulaceae.1b. Ipomea 1b-2b-3b-4b-5b-5a. Ipomea reptans Poir.

\subsection{Penyiapan simplisia dan pembuatan ekstrak etanol daun kangkung darat}

Sebanyak 5 kg kangkung darat segar dicuci hingga tidak ada kotoran, lalu dipotong kecilkecil dan selanjutnya dikeringkan di bawah sinar matahari dengan ditutup kain hitam. Pengeringan ini bertujuan untuk menghilangkan atau meminimalkan kandungan air pada tanaman, sehingga kandungan bahan aktif dapat terjaga dari kerusakan akibat hidrolisis air. Selain itu juga untuk mencegah tumbuhnya jamur, dan bakteri. Pengeringan tidak dilakukan di bawah sinar matahari langsung untuk mencegah kerusakan bahan pada tanaman (Marfu'ah et al., 2013). Setelah kering, tanaman selanjutnya dihaluskan menjadi serbuk dengan blender tanpa menggunakan air. Serbuk yang didapatkan seberat 476,60 g.

Penyerbukan ini sangat penting untuk mendapatkan ukuran partikel yang lebih kecil dan memaksimalkan efektifitas ekstraksi. Semakin kecil ukuran partikel, maka akan makin besar luas permukaannya. Hal ini akan meningkatkan kontak dengan cairan penyari sehingga penyarian menjadi lebih efektif. Semakin kecil ukuran partikel juga akan lebih meminimalkan tebal lapisan batas cairan penyari. Hal ini akan memudahkan cairan penyari untuk menarik senyawa aktif keluar dari dalam sel (Marfu'ah et al., 2013).

Ekstrak etanol kangkung darat dibuat dengan metode maserasi. Metode ini dipilih karena cara pengerjaan sederhana dan mudah dilakukan. Metode ini memungkinkan simplisia yang 
direndam dalam pelarut sampai meresap dan melunakkan susunan sel, sehingga zat-zat yang mudah terlarut akan terambil dan larut dalam cairan penyari (Ansel, 1989). Serbuk dimasukkan ke dalam bejana dan ditambahkan etanol 70\% sebanyak 3,57 1. Proses maserasi dilakukan selama 5 hari dalam bejana tertutup sambil dilakukan pengadukan setiap hari. Cairan penyari menggunakan etanol $70 \%$ dikarenakan lebih selektif, tidak beracun, netral, dapat bercampur dengan air pada segala perbandingan, dan memerlukan panas yang lebih sedikit untuk pemekatan. Selain itu untuk mencegah tumbuhnya kapang dan kuman karena keduanya sulit tumbuh dalam etanol dengan kadar di atas 20\% (Harborne, 1987). Proses penyarian ini menghasilkan ekstrak kental sebanyak 108,6 g dengan rendemen sebesar 22,78\%.

\subsection{Hasil uji efek sedasi}

Penelitian ini menggunakan mencit Balb/c jantan mengacu penelitian Anggara (2009). Pemilihan mencit dengan galur dan jenis kelamin sama bertujuan untuk mengendalikan faktor hormonal yang mungkin dapat mempengaruhi hasil pengukuran. Mencit diadaptasikan seminggu untuk meminimalkan efek stres yang mungkin akan mempengaruhi hasil. Sebelum percobaan dimulai, mencit dipuasakan dengan tetap diberi minum untuk menyamakan kondisi dan menghilangkan efek pengaruh makanan terhadap hasil.

Fenobarbital dipilih sebagai kontrol positif mengacu penelitian Anggara (2009), sedangkan akuades digunakan sebagai kontrol negatif dikarenakan ekstrak etanol kangkung darat dapat larut dalam air. Efek sedasi ditinjau dari durasi waktu tidur mencit setelah mendapat perlakuan. Durasi dihitung ketika mencit mulai tidur sampai mencit dapat membalikkan badan kembali ketika ditelentangkan. Adapun hasil pengamatan durasi waktu tidur mencit dapat dilihat pada tabel 1.

Tabel 1. Data durasi waktu tidur antar kelompok $(n=6)$

\begin{tabular}{cccccc}
\hline Kelompok & \multicolumn{5}{c}{ Durasi waktu tidur (menit) } \\
\cline { 2 - 6 } & Kontrol (-) & Kontrol (+) & $\begin{array}{c}\text { Dosis 8 } \\
\mathrm{mg} / \mathrm{kg} \mathrm{BB}\end{array}$ & $\begin{array}{c}\text { Dosis 16 } \\
\mathrm{mg} / \mathrm{kg} \mathrm{BB}\end{array}$ & $\begin{array}{c}\text { Dosis 32 } \\
\mathrm{mg} / \mathrm{kg} \text { BB }\end{array}$ \\
\hline $\mathbf{1}$ & 0 & 222 & 19 & 48 & 63 \\
\hline $\mathbf{2}$ & 0 & 235 & 15 & 63 & 80 \\
\hline $\mathbf{3}$ & 0 & 236 & 12 & 42 & 82 \\
\hline $\mathbf{4}$ & 0 & 235 & 15 & 57 & 67 \\
\hline $\mathbf{6}$ & 0 & 220 & 15 & 57 & 77 \\
\hline Mean $\mathbf{\pm}$ SD & 0 & 220 & 19 & 57 & 42 \\
\hline
\end{tabular}

Tabel 1 menunjukkan bahwa waktu durasi tidur kelompok kontrol positif jauh lebih besar dibandingkan kelompok dosis. Hasil kelompok dosis juga menunjukkan adanya kenaikan durasi waktu tidur seiring kenaikan dosis. Setelah dianalisa statistik, data menunjukkan terdistribusi normal dan homogen sehingga dilanjutkan dengan uji Oneway ANOVA. Hasil uji ANOVA menunjukkan nilai signifikansi sebesar 0,000 sehingga dianalisa lebih lanjut dengan uji Post Hoc Test untuk mengetahui perbedaan antar kelompok. Adapun hasil analisa dengan uji Post Hoc Test dapat dilihat pada tabel 2. 
Hasil pada tabel 2 menunjukkan bahwa secara statistik, semua kelompok dosis berbeda bermakna terhadap kelompok kontrol positif dan negatif. Kelompok dosis $8 \mathrm{mg} / \mathrm{kg}$ BB menunjukkan perbedaan bermakna terhadap kelompok dosis 16 dan $32 \mathrm{mg} / \mathrm{kg}$ BB. Akan tetapi hasil pada dosis $16 \mathrm{mg} / \mathrm{kgBB}$ tidak berbeda bermakna terhadap kelompok dosis $32 \mathrm{mg} / \mathrm{kgBB}$ meskipun durasi tidur mencit terlihat meningkat seiring kenaikan dosis. Hal ini menunjukkan bahwa pada dosis $8 \mathrm{mg} / \mathrm{kgBB}$ ekstrak kangkung darat ternyata juga sudah efektif menyebabkan efek sedasi meskipun belum sekuat fenobarbital. Efek sedasi ini diduga disebabkan karena adanya senyawa turunan lisergic acid dalam genus Ipomea yang diketahui berkhasiat sebagai halusinogenik (Marfu'ah et al., 2013).

Tabel 2. Hasil uji Post Hoc Test $(\mathrm{p}<0,05)$

\begin{tabular}{lccccc}
\hline \multicolumn{1}{c}{ Kelompok } & $\begin{array}{c}\text { Kontrol } \\
\text { negatif }\end{array}$ & $\begin{array}{c}\text { Kontrol } \\
\text { positif }\end{array}$ & $\begin{array}{c}\text { Dosis 8 } \\
\mathbf{m g} / \mathbf{k g ~ B B}\end{array}$ & $\begin{array}{c}\text { Dosis 16 } \\
\mathbf{m g} / \mathbf{k g ~ B B}\end{array}$ & $\begin{array}{c}\text { Dosis 32 } \\
\mathbf{m g} / \mathbf{k g ~ B B}\end{array}$ \\
\hline Kontrol negatif & - & $0,000^{*}$ & $0,000^{*}$ & $0,000^{*}$ & $0,001^{*}$ \\
\hline Kontrol positif & $0,000^{*}$ & - & $0,000^{*}$ & $0,000^{*}$ & $0,000^{*}$ \\
\hline Dosis 8 mg/kgBB & $0,000^{*}$ & $0,000^{*}$ & - & $0,000^{*}$ & $0,002^{*}$ \\
\hline Dosis 16 mg/kgBB & $0,000^{*}$ & $0,000^{*}$ & $0,000^{*}$ & - & 0,407 \\
\hline Dosis 32 mg/kgBB & $0,001^{*}$ & $0,000^{*}$ & $0,002^{*}$ & 0,407 & - \\
\hline
\end{tabular}

\section{Kesimpulan}

Ekstrak etanol kangkung darat (Ipomea reptans Poir) menunjukkan efek sedasi pada dosis 8,16 , dan $32 \mathrm{mg} / \mathrm{kg} \mathrm{BB}$, tetapi durasi lama tidur mencit tidak berbeda signifikan pada dosis 16 dan $32 \mathrm{mg} / \mathrm{kg} \mathrm{BB}$.

\section{Ucapan Terimakasih}

Penulis mengucapkan terima kasih kepada Anafia Azzahra Pratiwi yang telah membantu penelitian ini.

\section{Daftar Pustaka}

Anggara, R., 2009, Pengaruh Ekstrak Kangkung Darat (Ipomea reptans Poir) Terhadap Efek Sedasi Pada Mencit Balb/c., Universitas Diponegoro, Semarang.

Ansel, H.C., 1989, Pengantar Bentuk Sediaan Farmasi, diterjemahkan oleh Farida Ibrahim, Asmaniar, dan Iis Aisyah, Edisi IV, 244, 255-271, 607-608, UI Press., Jakarta.

Ariani, E., 2010, Tidur Untuk Sehat dan Awet Muda, Nirmala., Jakarta.

Harborne, J.B., 1987, Metode Fitokimia, diterjemahkan oleh Padmawinata, K., dan Sudiro, I., ITB., Bandung.

Listiani, A., 2007, Rahasia Tidur Malam yang Nyenyak, Interaksara., Jakarta.

Marfu'ah, I., Sudarso, dan Diniatik, 2013, Efek Sedasi Dari Variasi Dosis Ekstrak Etanol Daun Ubi Jalar (Ipomoea batatas L) Pada Mencit, Jurnal Pharmacy, Vol 10, 1-16.

Steenis, C.G.G.J.B., dan Eyma, P.J., 1978, Flora., Pradnya Paramita., Jakarta. 
Vogel, 2002, Drug Discovery and Evaluation, Pharmacological Assay, $2^{\text {nd }}$ Edition, SpringerVerlog Berlin Hiedelberg., Germany.

Wijayakusuma, H., 2008, Ramuan Lengkap Herbal Taklukkan Penyakit, Pustaka Bunda., Jakarta. 